\title{
pÿ The Scottish Enlightenment
}

\section{Tolonen, Mikko Sakari}

Sage

2013

pÿTolonen , M S 2013, The Scottish Enlightenment . in G Clayes, M S Cummings \& L T Sargent (eds), The Encyclopedia of Modern Political Thought . vol. 2 , Sage , Los Angeles, CA , pp. 740-745 . https://doi.org/10.4135/9781452234168

http://hdl.handle.net/10138/156263

https://doi.org/10.4135/9781452234168

cc_by

submittedVersion

Downloaded from Helda, University of Helsinki institutional repository.

This is an electronic reprint of the original article.

This reprint may differ from the original in pagination and typographic detail.

Please cite the original version. 
NOVEMBER 1, 2013

\section{SCOT'TISH ENLIGHTENMENT}

in Gregory Clayes (ed.), The Encyclopedia of Modern Political Thought, SAGE 


\section{MIKKO TOLONEN, SCOTTISH ENLIGHTENMENT}

Eighteenth-century Scotland enjoyed a rare share of intellectual vivacity. The term "Scottish Enlightenment" is often used to denote a philosophical period (from approximately the $1720 \mathrm{~s}$ to the 1820s) forming a part of the intellectual foundation of Western modernity. While the literary flourish of eighteenth-century Scotland is universally admired, the concept of the Scottish Enlightenment and whether there were one or many Enlightenments remain contested issues. The term Scottish Enlightenment was not used by eighteenth-century contemporaries, but it was in fact first coined at the turn of the twentieth century. The existence, content and relevance of the Scottish Enlightenment have been sources of growing debate since the 1960s. This article will outline the Scottish Enlightenment by considering its nature and thinkers, by framing its historical and intellectual context, by drafting its main moral and political features and finally by taking into account its legacy as a platform for Western modernity.

Around the 1750s, the small Scottish population (only about 1.3 million inhabitants) was avant-garde in many discussions that have since shaped the modern intellectual atmosphere with regard to natural science, theology, philosophy, and especially conceptions of civil society. Eighteenth-century Scotland witnessed the emergence of the well-known intellectual giants Francis Hutcheson, David Hume and Adam Smith. This period is perhaps most famous for elaborate projects aiming to outline the "Science of Man" and ranging from epistemological questions of human understanding to conclusions about aesthetics, morals and politics (e.g. Hume, Treatise of human nature, 1739-1740). In political philosophy, the Scots of the Enlightenment period were the first to concretely underscore the relevance of commerce in our historical understanding of the emergence of civil society. 
The Scottish Enlightenment can also be used as a term denoting an intellectual movement (not limited to the abovementioned famous philosophers) that was Whig and liberal-minded in politics and moderate Presbyterian in religion. Although there are many crucial differences in moral and political thought of the eighteenth-century Scots, the Scottish Enlightenment was a unified project because it had a common aim: the progress of humanity. It was a movement founded at the University and the Church in all the major university towns of eighteenth-century Scotland: Edinburgh, Glasgow, St Andrews and Aberdeen. It formed a moderate culture of clergymen, professors and laymen striving for cosmopolitan universality. It was a culture that also took root in different clubs and societies, founded for the purpose of promoting the progress of humanity. The Scottish Enlightenment also had an idiosyncratically practical side to it, exemplified in different reform attempts in the Highlands that at the time were considered uncivilised.

The authors of the Scottish Enlightenment worked closely with a network of patrons and book publishers in Edinburgh, Glasgow and London, which was crucial in making an actual intellectual impact. A list of the characters of the Scottish Enlightenment includes: Francis Hutcheson, David Hume, Adam Smith, Adam Ferguson, William Robertson, Henry Home, John Millar, Thomas Reid, Hugh Blair, Alexander Gerard, George Campbell, Joseph Black, William Cullen, Allan Ramsay, Lord Monboddo, Alexander Carlyle, John Gregory, Sir David Dalrymple, James Hutton, Robert Adam, James Beattie, Henry Mackenzie, Dugald Stewart, and others.

\section{Context}

The main historical context for the Scottish Enlightenment was the Act of Union of 1707, which formed Great Britain and marked the dissolution of the Scottish parliament. Scotland 
in the early eighteenth century was a relatively poor and backward country, although it had had its share of intellectual cultivation in prior centuries. Any claims that the intellectual vivacity of the Scottish Enlightenment emerged solely because of the Union are unfounded. England, Scotland and Wales had not only common denominators facilitating the Union (geography, language and protestant religion), but also differences (e.g. the English legal system was based on the common law tradition whereas the Scots had followed the central European tradition of founding their legal system on Roman law). The eighteenth-century political framework was dominated by considerations of the European state system, and French absolutist attempts at universal monarchy largely shaped the intellectual atmosphere in Britain. A foundational question for the Scottish Enlightenment was the question of a commercial empire and Scotland's interest in securing its overseas trade by being a part of Great Britain. Eighteenth-century Scotland witnessed also rebellions in the form of Jacobite risings in 1715 and 1745 threatening the Union.

The Scottish Enlightenment can be seen as a catalyst of many of the most relevant seventeenth-century intellectual developments, especially in the tradition of natural law. The eighteenth-century Scots also read their share of French moralist views alongside Thomas Hobbes's conception of the state of nature, John Locke's taxonomy of mind, and other seventeenth-century intellectual achievements. In accordance with Locke's empirical principles, perhaps the two most relevant authors shaping the ideas of the Scottish Enlightenment were Anthony Ashley Cooper, the third Earl of Shaftesbury and the Dutchborn controversialist Bernard Mandeville. Shaftesbury's ideas of sociability had a profound impact on the moderate culture of eighteenth-century Scotland with regard to humankind's capacity for benevolence, whereas Mandeville's more realistic outlook emphasised egoistic tendencies in human actions. The dichotomy between these thinkers also sparked debates dividing the Scottish Enlightenment into different camps. 
Perhaps the greatest impact of the Scottish Enlightenment on Western thought has been the idea that morality is founded on sentiment rather than reason, an idea developed mainly by Hutcheson and accepted by Hume, Smith and others. This development can be seen as part of the empirical tradition in which the history of science also plays a crucial role and in which the significance of Francis Bacon, Robert Boyle, and Locke is evident.

\section{Moral and political}

One characteristic feature of eighteenth-century thought is that moral and political spheres overlap. Similarly, eighteenth-century economic ideas must be considered part of political economy because economic theory as such did not yet exist. In the Scottish Enlightenment everything that was part of moral theory was also considered part of political thought and vice versa. This stemmed from the empirical background of the Scottish Enlightenment, which began by first defining human understanding and human nature, and from this perspective aimed towards the common good, policy making and the generation of wealth by managing the nation's resources.

The main moral dispute of the Scottish Enlightenment concerned passions. Whereas previous Christian traditions taught that morality required passions to be controlled and suppressed, eighteenth-century Europe saw a growing number of authors suggesting that even vice could sometimes be publicly beneficial and that the passions of pride and selfinterest need not be repressed, only redirected so that they prove useful. This was a foundational matter of debate in the Scottish Enlightenment, which generated various fruitful contemporary accounts of the historical development of civil society. In particular, the question of luxurious consumption beyond one's basic needs divided opinions that varied from claims of public and moral corruption to sophisticated arguments of public utility. One 
of the main writings on this topic is Adam Ferguson's Essay on the History of Civil Society, 1769.

Hand in hand with the question of the role of self-interest and pride in civil society went the question of moral motivation: Are people universally benevolent by nature? Many authors of the Scottish Enlightenment believed that human beings have a moral sense that can, like vision be distorted, but which also serves as a foundation for moral motivation. Some authors, most notably Hume, denied the claim about the universal benevolence by emphasising the role of conventions in social formation. Debates about hedonism and the role of utility in civil society were common in eighteenth-century Scotland, as exemplified in Smith's Theory of Moral Sentiments, 1759.

Perhaps the most important moral and political concept of the Scottish Enlightenment was justice. Questions of the origin of property and rightful ownership drew largely from natural law, which had a strong institutional basis in eighteenth-century Scotland. Most authors criticised seventeenth-century contract theories and Scottish historical writing developed together with discussions of property, justice, political obligation and the legitimacy of government. As an outcome the social theory of the Scottish Enlightenment was rooted in historical understanding of the development of civil society. The question of justice was also a moral question, which extended the discussion of the natural and artificial sociability of man. Although Hume is best known today for his epistemological conclusions, his reputation in the eighteenth century relied almost solely on his voluminous History of England. Hume's views on justice (and causation) were attacked particularly by commonsense philosopher Thomas Reid.

Alongside justice, another critical discussion about conventions concerned politeness. Politeness was a crucial concept in the Scottish Enlightenment mainly based on Shaftesbury's ideas, which provided a framework for civility within the boundaries of virtue, 
in contrast to Orthodox Calvinism and the external tradition of court civility. Hume, following Mandeville, claimed that these views based on natural sociability were contrary to human nature and thus untenable. However, politeness for Hume was just as important concept as it was for the followers of Shaftesbury. The difference was that Hume claimed that politeness was an external custom and an artificial virtue. The opinions of the Scottish Enlightenment were thus also split concerning politeness.

Despite their differences, eighteenth-century Scottish authors had a common aim in politics: global civilisation. Interestingly, the thinkers of the Scottish Enlightenment approached interstate relations in Europe from the perspective of human nature, which gave their arguments a scope of universality. At the same time, their political views varied from the political radicalism of Hutcheson to more conservative views expressed by Hume, Smith and Dugald Stewart after the French Revolution.

The foundational moral and political issue of the Scottish Enlightenment was commerce. Although Adam Smith had predecessors, he was the first to explicitly identify the relevance of the unintended, beneficial consequences of self-interested actions in the marketplace. Smith also emphasised that comparison in the development of a civil society shows that the poor of commercial society are better off than the rich of previous stages (assessments were made between Europe's "civilised monarchies" and Native American tribal communities). This was not an argument to be ignored, and when combined with growing attempts to break free from mercantilism by emphasising the role of the division of labour, productivity and how to secure the advantages of rich countries from countries underselling their products, these ideas of homo economicus, as outlined in Smith's An Inquiry into the Nature and Causes of the Wealth of Nations, 1776, began to form a platform for Western modernity. 
While commercial society was considered the most advanced state of human sociability, questions about the imperfections of the market, instead of the full-fledged promotion of laissez-faire liberalism, dominated discussions of political economy. One such question was whether Great Britain should forfeit its overseas colonies and grant independence to the United States of America. This does not mean, however, that Smith and others would have been supporters of uncontrolled free trade and global shareholding without interference by local governments. Smith also had a genuine interest in the condition of the poor and ordinary labourers. Nor did this entail ideas of social reform or redistribution of wealth as a state-run strategy. Smith did, however, provide a seed for the idea of universal education of the poor.

\section{Legacy}

Eighteenth-century Scotland had a cosmopolitan character which cultivated a relationship with other European countries sharing influences with French eighteenth-century thought in particular and forming an Atlantic dimension through the work of John Witherspoon and others towards the end of the Scottish Enlightenment. The Enlightenment period cannot be described as a teleological progress of reason and steady decline of religion. Questions regarding the political organisation of the church, the natural history of religion and matters of faith were an integral part of the Scottish Enlightenment. It is therefore only natural that religious toleration was one of the main issues of the era.

As the political framework changed during the eighteenth century, and wars turned out to be too expensive for individual states to handle, so the emphasis of the Scottish Enlightenment shifted from debates about moral sense and natural sociability to discussions of the European state system and the commercial empire of the sea. Modern state structures 
began to emerge, taxation slowly became more regular, the banking industry was established, and questions of paper money and public debt were fervently debated. This had a crucial impact on the Scottish Enlightenment, so it is understandable that Adam Smith, for example, who was first and foremost a moral philosopher, is best known as the father of classical economics.

Political economy was an integral part of the legacy of the Scottish Enlightenment for Western modernity, but equally important were questions of constitutional balance and what kind of role a sovereign should have in a mixed form of government in which political power is shared between parliament and a monarch. Authors of the Scottish Enlightenment were amply constructing their political views on the concepts of equity and equality, at the same time, democracy was not part of their common vocabulary. In short, the Scottish Enlightenment formed a platform for Western modernity, but it was not the world we inhabit today.

See Also Civil Society; Economics and Political Thought; Eighteenth Century Political Thought; English Enlightenment; Ferguson, Adam; French Enlightenment; German Enlightenment; Human Nature, Theories of; Hume, David; Natural Law; Property, Theories of; Smith, Adam; State of Nature.

Mikko Tolonen

University of Helsinki

\section{Bibliography}

Forbes, Duncan. Hume's philosophical politics, Cambridge: Cambridge University Press, 1975. 
Haakonssen, Knud. Science of the legislator. The natural jurisprudence of David Hume and Adam Smith, Cambridge: Cambridge University Press, 1982.

Hirschman, Albert O. The passions and the interests. Political arguments for capitalism before its triumph, Princeton: Princeton University Press, 1977.

Hont, Istvan. Jealousy of trade. International competition and the nation-state in historical perspective, Harvard: Harvard University Press, 2005.

Hundert, E. J. Enlightenment's Fable. Bernard Mandeville and the discovery of society, Cambridge: Cambridge University Press, 1994.

Moore, James. “The Social Background of Hume's Science of Human Nature”, in McGill Hume Studies. Studies in Hume and Scottish Philosophy, David Fate Norton, Nicholas Capaldi and Wade L. Robinson, eds., San Diego: Austin Hill Press, 1979: 23-42.

Robertson, John. The case for the enlightenment, Cambridge: Cambridge University Press, 2005.

Sher, Richard. Church and university in the Scottish Enlightenment, Princeton: Princeton University Press, 1985.

Stewart, M. A. ed., Studies in the philosophy of the Scottish Enlightenment, Oxford: Oxford University Press, 1990. 
Winch, Donald. Riches and poverty. An intellectual history of political economy in Britain, 1750-1834, Cambridge: Cambridge University Press, 1996. 